\title{
Convergent in situ Generation of Both Transketolase Substrates via Transaminase and Aldolase Reactions for Sequential One-Pot, Three-Step Cascade Synthesis of Ketoses
}

\author{
Marion Lorillière, ${ }^{[\mathrm{a}]}$ Christine Guérard-Hélaine, ${ }^{[\mathrm{a}]}$ Thierry Gefflaut, ${ }^{[\mathrm{a}]}$ Wolf-Dieter Fessner, ${ }^{[\mathrm{b}]}$ \\ Pere Clapés, ${ }^{[c]}$ Franck Charmantray, ${ }^{*[a]}$ and Laurence Hecquet* ${ }^{*[a]}$
}

We describe an efficient three-enzyme, sequential one-pot cascade reaction where both transketolase substrates are generated in situ in a convergent fashion. The nucleophilic donor substrate hydroxypyruvate was obtained from L-serine and pyruvate by a transaminase-catalyzed reaction. In parallel, three different (2S)- $\alpha$-hydroxylated aldehydes, L-glyceraldehyde, D-threose, and L-erythrose, were generated as electrophilic acceptors from simple achiral compounds glycolaldehyde and formaldehyde by D-fructose- 6 -phosphate aldolase catalysis. The

\section{Introduction}

The need for greener and more sustainable chemical production $^{[1]}$ has seen enzymatic strategies to emerge as a powerful approach to the eco-friendly, highly selective synthesis of valuable chiral compounds. To compete with the productivity of traditional methods, the use of two or even more enzymes in cascade can considerably improve the efficiency of a multistage synthesis by obviating the isolation of intermediates, thus saving time, resources, reagents and energy, while reducing waste. ${ }^{[2-4]}$ Cascade reactions can be performed along a simultaneous one-pot strategy when all the enzyme requirements are compatible. To meet limitations, such as substrate/product/reagent inhibition or incompatibility of reac-

[a] Dr. M. Lorillière, Dr. C. Guérard-Hélaine, Prof. T. Gefflaut, Dr. F. Charmantray, Prof. L. Hecquet

Université Clermont Auvergne, CNRS, SIGMA Clermont Institut de Chimie de Clermont-Ferrand (ICCF)

Clermont-Ferrand F63000 (France)

E-mail: Laurence.hecquet@uca.fr

Franck.Charmantray@uca.fr

[b] Prof. Dr. W.-D. Fessner

Institut für Organische Chemie und Biochemie

Technische Universität Darmstadt

Darmstadt 64287 (Germany)

[c] Prof. P. Clapés

Biotransformation and Bioactive Molecules Group

Instituto de Química Avanzada de Cataluña

IQAC-CSIC Jordi

Barcelona 08034 (Spain) compatibility of the three enzymes was studied in terms of temperature, enzyme ratio and substrate concentration. The efficiency of the process relied on the irreversibility of the transketolase reaction, driving a shift of the reversible transamination reaction and securing the complete conversion of all substrates. Three valuable $(3 S, 4 S)$-ketoses, L-ribulose, D-tagatose, and L-psicose were obtained in good yields with high diastereoselectivity.

tion conditions ( $\mathrm{pH}$, temperature), a telescoped, sequential onepot procedure can be used. ${ }^{[2]}$

Chiral polyols, regarded as highly valuable compounds in various fields, can be obtained by stereoselective carbon-carbon bond formation. ${ }^{[5,6]}$ Especially, transketolase (TK, EC 2.2.1.1) is a powerful thiamine diphosphate-dependent biocatalyst that allows a two-carbon chain elongation by transferring an $\alpha$ hydroxy carbonyl (ketol) group from a ketone donor to an aldehyde acceptor, to produce a corresponding $C_{n+2}$ ketose (Scheme 1).

In the pentose phosphate metabolism, TK catalyzes a ketol transfer reaction for the reversible equilibration of ketoses and aldoses carrying a terminal phosphate ester group. Previous in vitro studies showed that non-phosphorylated aldose compounds can also be used as TK substrates, yielding the equivalent free ketoses in one step. In particular, irreversible release of carbon dioxide from hydroxypyruvate (HPA) as donor kinetically drives the conversion, rendering TK a powerful tool for the asymmetric synthesis of ketoses and related acyloin compounds. ${ }^{[7,8]}$

The studies on TK acceptor substrate specificity revealed that non-phosphorylated $\alpha$-hydroxylated aldehydes with short carbon chains $\left(C_{2}-C_{3}\right)$ gave the highest TK activities. The new asymmetric center at $\mathrm{C} 3$ of the $C_{n+2}$ ketose product is formed

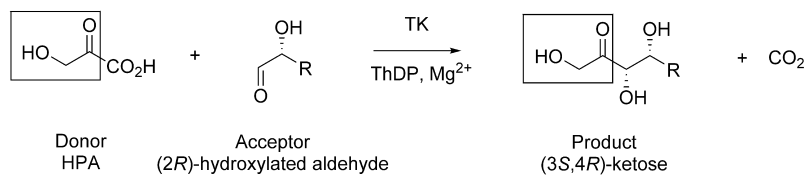

Scheme 1. Irreversible reaction catalyzed by TK using hydroxypyruvate (HPA) as donor substrate with (2R)-hydroxyaldehydes as acceptor substrates. 
with high stereoselectivity for an (S) configuration. In addition, the enzyme is highly enantioselective with chiral $\alpha$-hydroxy aldehydes, and converts the (2R)-epimers with high preference, thus leading to $(3 S, 4 R)$-configured ketoses. For biocatalytic applications, mesophilic TKs from Saccharomyces cerevisiae and from Escherichia coli have been largely used and optimized by mutagenesis. ${ }^{[9,10]}$ We have identified the first thermostable TK from Geobacillus stearothermophilus $\left(\mathrm{TK}_{\mathrm{gst}}\right)$ that offers significantly improved stability at high temperature, ${ }^{[11]}$ more robustness towards non-usual reaction conditions ${ }^{[12]}$ and a broadened substrate spectrum obtained by in vitro evolution towards (2S)hydroxylated, ${ }^{[13]}$ aliphatic ${ }^{[14]}$ and aromatic aldehydes ${ }^{[15]}$ and also towards HPA analogs as new donor substrates. ${ }^{[16]}$

The purpose of this study was to optimize the synthesis of highly valuable natural $(3 S, 4 S)$-ketoses from (2S)-hydroxyaldehydes. While the synthesis of such compounds is inaccessible using mesophilic TKs, we could recently show that $\mathrm{TK}_{\mathrm{gst}}$ catalysis enabled best yields upon reaction at $60^{\circ} \mathrm{C}$ in a reasonable time frame (8-24 h). ${ }^{[11,13]}$ To make this $\mathrm{TK}_{\mathrm{gst}}$-catalyzed process greener and more sustainable, a major challenge was to generate the donor HPA as well as the acceptor substrates in situ in a onepot procedure, not only to avoid the costly purchase or chemical synthesis of these compounds, but also to counteract their limited stability at $60^{\circ} \mathrm{C}$ (Scheme 2). HPA is particularly unstable at high temperature but can be produced in situ from L-serine (L-Ser) by transamination to a ketoacid as amino group acceptor. ${ }^{[17]}$ For this purpose, we recently introduced the thermostable L- $\alpha$-transaminase from Thermosinus carboxydivorans $\left(\mathrm{TA}_{\mathrm{tca}}\right)$, which was identified, characterized and coupled with thermostable $\mathrm{TK}_{\mathrm{gst}}{ }^{\left[{ }^{[18]}\right.}$ The targeted (2S) hydroxyaldehydes - L-glyceraldehyde 1, D-threose 2, and L-erythrose 3 - can be synthesized from cheap non-chiral starting materials such as glycolaldehyde (GA) and formaldehyde (FA) by enzymatic aldol reactions catalyzed by D-fructose-6-phosphate aldolase from Escherichia coli (FSA ecoi wild-type or variants). ${ }^{[19]}$ The compatibility of FSA and TK-catalyzed reactions has been previously demonstrated for the synthesis of phosphorylated sugars. ${ }^{[2]}$ Here, we have investigated the best conditions (i.e., temperature, enzyme ratios, substrate concentrations) to combine the three individual reactions catalyzed by TA, FSA and TK into a convergent one-pot procedure. This procedure was then applied to the synthesis of three rare $(3 S, 4 S)$ ketoses, namely Lribulose $4,^{[21]}$ D-tagatose $5_{1}^{[22]}$ and L-psicose $6,{ }^{[23]}$ which are highly valuable compounds in the pharmaceutical and food sectors.

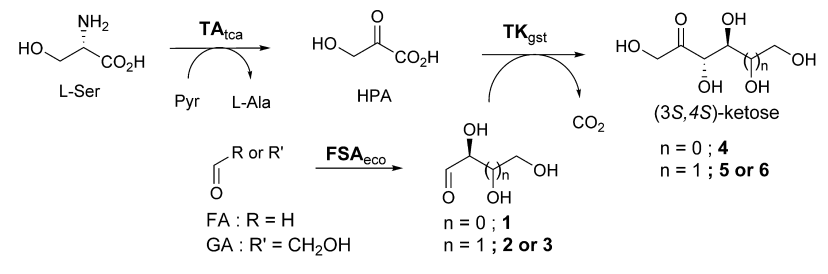

Scheme 2. One-pot cascade reaction for the synthesis of ketoses 4-6 by $\mathrm{TK}_{\mathrm{gst}}$ with convergent in situ generation of HPA using $\mathrm{TA}_{\mathrm{tca}}$ and aldehydes 1-3 using FSA $_{\text {eco. }}$.

\section{Results and Discussion}

The convergent reaction strategy illustrated in Scheme 2 entails the practical selectivity problems that the substrates FA and/or GA involved in the FSA reaction for the generation of Lglyceraldehyde 1, D-threose 2 and L-erythrose 3 are also good substrates of $\mathrm{TK}_{\mathrm{gst}}$ and could also be consumed by undesired transamination from L-Ser. Therefore, the aldolase catalyzed synthesis of $\mathrm{TK}_{\mathrm{gst}}$ acceptors 1-3 in the first stage had to be uncoupled from the remaining steps. Then, in a telescoped second stage, all other enzymes and substrates could be added simultaneously for in situ generation of HPA donor and for the final carboligation leading to L-ribulose 4, D-tagatose 5 and Lpsicose 6 .

\section{In situ Generation of Aldehydes 1-3 by FSA}

FSA $_{\text {eco }}{ }^{[24]}$ belongs to the class I aldolases and catalyzes in vivo the reversible stereoselective addition of dihydroxyacetone to D-glyceraldehyde-3-phosphate to form D-fructose-6-phosphate. The aldolase showed a remarkable tolerance to a large panel of nucleophilic substrates, such as non-phosphorylated ketones, and aldehydes such as FA, acetaldehyde and GA. ${ }^{[25]}$ In addition, efficient FSA $_{\text {eco }}$ variants could be obtained by enzyme engineering to broaden the nucleophile scope. ${ }^{[26]}$ The enzymatic syntheses of 1, 2 and 3 have been recently achieved with wildtype and variants of FSA $_{\text {eco }}$ using cheap, achiral aldehydes FA and $G A{ }^{[19]}$ The original procedures had to be slightly modified for the purpose of this work (Table 1). The three FSA-catalyzed reactions were monitored by HPLC and by quantitative ${ }^{1} \mathrm{H}$ NMR analysis to observe the conversion of aldehydes and the simultaneous formation of the ketose products (ESI).

The synthesis of L-glyceraldehyde 1 from FA and GA was catalyzed by wild-type-FSA ${ }_{\text {eco }}{ }^{[19]}$ To prevent the self-condensation of GA leading to the production of D-threose 2 , the strategy required an excess of FA (100 mM) over GA $(50 \mathrm{mM})$, which resulted in a $60 \%$ conversion of GA after $24 \mathrm{~h}$ at $25^{\circ} \mathrm{C}$. Because the wild-type $\mathrm{FSA}_{\text {eco }}$ is a thermostable enzyme (half-life 8 days, $30 \mathrm{~h}$ and $16 \mathrm{~h}$, at $55^{\circ} \mathrm{C}, 65^{\circ} \mathrm{C}$ and $75^{\circ} \mathrm{C}$, respectively), we tested if reactions could be promoted at higher temperatures. Indeed, reactions carried out at $50^{\circ} \mathrm{C}$ led to a complete conversion of GA within $19 \mathrm{~h}$.

D-Threose $(2 S, 3 R) \mathbf{2}$ or L-erythrose $(2 S, 3 S) \mathbf{3}$ were both obtained by the condensation of two GA molecules with catalysis by two different FSA $_{\text {eco }}$ variants, A129G or A165G/ $\mathrm{S} 166 \mathrm{P}$, respectively, which control an opposite stereoselectivity at C3. ${ }^{[19]}$ The synthesis of $\mathbf{2}$ was fast, but compromised by (i) the retroaldolization of 2 releasing $G A$, and (ii) the condensation of 2 to GA yielding D-idose. To avoid these undesired complications, use of GA at $200 \mathrm{mM}$ with $4 \mathrm{mg}$ of $\mathrm{A} 129 \mathrm{G}$ at $25^{\circ} \mathrm{C}$ led to clean formation of D-threose 2 with $98 \%$ conversion of GA in $24 \mathrm{~h}$, without formation of D-idose as shown by NMR analysis of the reaction mixture. To reduce the reaction time, we also tested elevated temperatures, but this caused the denaturation of the $\mathrm{FSA}_{\text {eco }}$ variant. Aldehyde $\mathbf{3}$ was obtained from the selfaddition of GA catalyzed by $\mathrm{FSA}_{\text {eco }}$ variant $\mathrm{A} 165 \mathrm{G} / \mathrm{S} 166 \mathrm{P}$ 


\begin{tabular}{|c|c|c|c|c|c|c|c|c|}
\hline $\begin{array}{l}\text { Ser } \\
\mathrm{mM}\end{array}$ & $\begin{array}{l}\text { Pyr } \\
\mathrm{mM}\end{array}$ & $\begin{array}{l}\text { Aldehyde } \\
(\mathrm{mM})^{[\mathrm{a}]}\end{array}$ & $\begin{array}{l}\mathrm{TA}_{\mathrm{tca}} / \mathrm{TK}_{\mathrm{gs}} \\
(\mathrm{mg} / \mathrm{mg})\end{array}$ & $\begin{array}{l}\text { Ketose } \\
\text { product }\end{array}$ & $\begin{array}{l}\text { Reaction } \\
\text { time }(\mathrm{h})\end{array}$ & $\begin{array}{l}\text { Aldehyde } \\
\text { Conversion } \\
\text { rate } \%^{[a]}\end{array}$ & $\begin{array}{l}\text { Isolated } \\
\text { yield (\%) }\end{array}$ & $d e(\%)^{[b]}$ \\
\hline 150 & 50 & $1-(50)$ & $4.8 / 6$ & & 24 & $>95$ & 53 & $>95$ \\
\hline 150 & 100 & $2-(50)$ & $4.8 / 10$ & & 96 & $>95$ & 55 & $>95$ \\
\hline 150 & 100 & 3-(50) & $4.8 / 10$ & & 96 & $>95$ & 49 & $>95$ \\
\hline
\end{tabular}

allowing the formation of the $(2 S, 3 S)$ configuration, which is

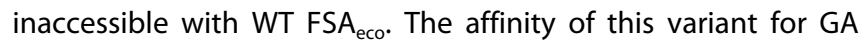
being very low, about six times more enzyme than in the previous reaction ( $25 \mathrm{mg}$ ) was required to convert $96 \%$ of GA $(200 \mathrm{mM})$ in 10 days at $25^{\circ} \mathrm{C} .{ }^{[19]}$ Again, a higher temperature was tried to shorten reaction time but also caused enzyme precipitation.

Finally, HPLC and NMR analysis validated that the three aldehydes 1, 2 and 3 were obtained with excellent yield and with high diastereoselectivity (>95\%). Subsequently, the reaction mixtures obtained were subjected directly without purification to the subsequent synthesis of the corresponding ketoses 3,4 , and 5 .

\section{Synthesis of Ketoses 4-6 from Aldehydes 1-3 and in situ Generated HPA by TA $_{\text {tca }}$ Coupled withTK gst $_{\text {t }}$}

Aldehydes 1-3 present a (2S)-configuration, which is opposite to the strongly preferred natural $(2 R)$-substrates of WT TK Previously, we showed that increased conversion of non-natural (2S)-substrates could be promoted by high temperature $\left(60^{\circ} \mathrm{C}\right)$, however, which was also resulting in HPA degradation over time. ${ }^{[11,13 a]}$ To overcome this problem, we found an efficient alternative to using synthetic HPA, consisting of the generation of HPA in situ by using a thermostable transaminase from Thermosinus carboxydivorans ( $\mathrm{TA}_{\mathrm{tca}}$ ). The thermostability of both $\mathrm{TA}_{\text {tca }}$ and $\mathrm{TK}_{\mathrm{gst}}$ at $60^{\circ} \mathrm{C}$ and the irreversibility of the TK reaction, allowing an equilibrium shift of the TA reaction towards HPA, are of particular interest. Thus, $\mathrm{TA}_{\mathrm{tca}}$ with L-Ser and pyruvate (Pyr) as substrates, pyridoxal phosphate (PLP) as cofactor, and $\mathrm{TK}_{\mathrm{gst}}$, with both its cofactors thiamine diphosphate (ThDP) and $\mathrm{MgCl}_{2}$, were simultaneously added to the aldol reaction mixture containing aldehydes 1-3, obtained with FSA $_{\text {eco }}$ in the first stage. We observed that all substrates and reagents assayed at $60^{\circ} \mathrm{C}$ were found to be stable except Pyr, which slowly decomposed with a half-life of 4 days. ${ }^{[18]}$

In order to study the influence of different enzyme quantities and substrate concentrations, small scale reaction mixtures were monitored in situ by ${ }^{1} \mathrm{H}$ NMR analysis against 3trimethylsilyl-2,2,3,3-tetradeuteropropionate $\left(\mathrm{TSP}_{-} \mathrm{d}_{4}\right)$ as an internal standard. Thereby, we could quantify the individual conversion rates of aldehydes and Pyr along with the formation of ketose products. The reaction mixtures containing aldehydes 1, 2 and 3 obtained by FSA eco catalysis were diluted to a final concentration of $50 \mathrm{mM}$. The ratio $\mathrm{TA}_{\mathrm{tca}} / \mathrm{TK}_{\mathrm{gst}}$ was adjusted to avoid an accumulation of HPA while allowing its gradual conversion into ketoses 4-6. The best conversion rates of aldehydes were reached by using 1.5 equivalents of L-Ser in combination with 1 equivalent of Pyr. In the case of D-threose 2 and L-erythrose 3, for which $\mathrm{TK}_{\mathrm{gst}}$ shows lower activities, a corresponding larger quantity of $\mathrm{TK}_{\mathrm{gst}}\left(4.8 \mathrm{mg} \mathrm{TA}_{\mathrm{tca}} / 10 \mathrm{mg} \mathrm{TK}_{\mathrm{gst}}\right)$ had to be used. To avoid the known inhibition of $\mathrm{TA}_{\mathrm{tca}}$ by Pyr at concentrations above $50 \mathrm{mM}^{[18]}$ this substrate was added in two portions, the second after complete disappearance of the first fraction.

Under such adjusted conditions, we observed the total conversion of aldehydes 1-3 and simultaneously the quantitative formation of the corresponding ketose products (Table 2). Finally, L-ribulose 4, D-tagatose 5 and L-psicose 6 were isolated in good yields of $53 \%, 55 \%$ and $49 \%$, respectively. It is noteworthy that the isolated yields of compounds 4-6 obtained by following the novel cascade process were 4-5 times higher than those obtained with synthetic Li-HPA and commercially available substrates 1-3, which were reported as $11 \%$, ${ }^{[13 a]}$ $13 \%,{ }^{[13 \mathrm{~b}]}$ and $10 \%,{ }^{[13 \mathrm{~b}]}$ respectively. The three L-erythro $(3 \mathrm{~S}, 4 \mathrm{~S})$ ketoses were obtained in optically pure form with high diastereoselectivity (de $>95 \%$ ). The absolute configurations of 4-6 were further confirmed by comparing their optical rotations with those reported in the literature. These characterization data confirmed that the three $\mathrm{TK}_{\mathrm{gst}}$-catalyzed reactions each led 
to a single ketose with the expected L-erythro $(3 S, 4 S)$ configuration, consistent with the stereoselectivity observed with other aldehyde acceptors by $\mathrm{TK}_{\mathrm{gst}}$ catalysis at elevated temperatures. ${ }^{[10,12,13]}$

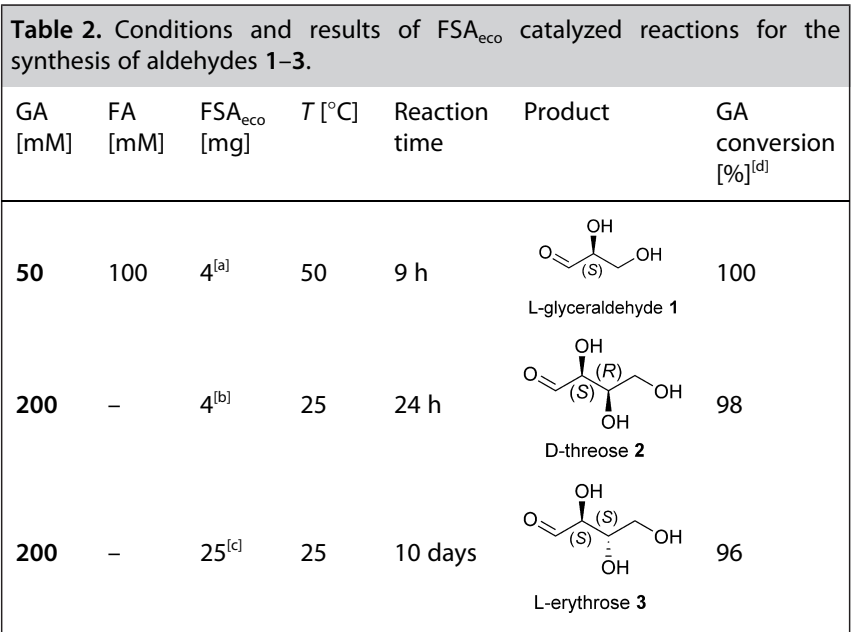

[a] Wild-type FSA ecor [b] Variant FSA eco A129G, [c] Variant FSA eco A165G/ $\mathrm{S} 166 \mathrm{P}$, [d] Determined by HPLC and quantitative ${ }^{1} \mathrm{H}$ NMR relative to $3-$ trimethylsilyl-2,2,3,3-tetradeuteropropionate $\left(\mathrm{TSP}_{\mathrm{S}} \mathrm{d}_{4}\right)$ as internal standard.

\section{Conclusions}

The synthesis of three $(3 S, 4 S)$-ketoses, L-ribulose $\mathbf{4}$, D-tagatose 5 and L-psicose 6 , which are highly valuable compounds, was performed from in situ generated (2S)- $\alpha$-hydroxy aldehydes 1-3 and HPA using an efficient sequential one-pot, three-step cascade sequence catalyzed by $\mathrm{FSA}_{\text {eco }}$ and thermostable $\mathrm{TA}_{\text {tca }}$ and $\mathrm{TK}_{\mathrm{gst}}$. This convergent procedure allowed circumventing the instability of HPA and the cost of expensive aldehyde precursors. The efficiency of this one-pot, three-step cascade process relied on the demonstrated compatibility of the three enzyme types. It allowed for an in situ generation of aldehydes catalyzed by FSA $_{\text {eco }}$ variants from achiral, cheap aldehydes GA and FA. Moreover, also the sensitive HPA could be generated by $\mathrm{TA}_{\mathrm{tca}}$ from L-Ser coupled with its irreversible consumption in a $\mathrm{TK}_{\mathrm{gst}}$ reaction, thus avoiding its accumulation and decomposition. In addition, the thermostability of $\mathrm{TA}_{\mathrm{tca}}$ and $\mathrm{TK}_{\mathrm{gst}}$ enabled the process to be performed at $60^{\circ} \mathrm{C}$, resulting in increased activities towards the (2S)-configured $\alpha$-hydroxyaldehydes, which are poor $\mathrm{TK}_{\mathrm{gst}}$ substrates at $25^{\circ} \mathrm{C}$. Consequently, excellent conversion rates in a reasonable time (24-96 h) were attained. This environmentally friendly, straightforward approach offers a useful alternative to the conventional chemical synthesis of these compounds, and seems applicable to a wider scope of related products, using other wild-type or variant carboligation catalysts.

\section{Experimental Section}

General experimental. Thermosinus carboxydivorans DSM 14886 was purchased from DSMZ, E. coli strains BL21(DE3)pLysE strain from Invitrogen. Reagents for molecular biology were obtained from Life Technologies. Sodium chloride was from Roth. L-Ser, Pyr, imidazole, ammonium sulphate and potassium chloride were purchased from Alfa Aesar. Pyridoxal 5-phosphate monohydrate (PLP) was from Acros Organics. L-Glyceraldehyde was from Molekula. Ni-NTA resin was from Qiagen. The 96-well microplates were shaken and incubated in a Titramax 1000 incubator (Heidolph). Lyophilization was carried out with a Triad Labconco dryer. UV-visible absorbances were measured using a Safire II-Basic plate reader from Tecan and a Perkin Elmer Lambda 25 spectrophotometer enabling Peltier-effect temperature control. MachereyNagel GmbH \& Co KG 60 F254 silica gel TLC plates and MachereyNagel GmbH \& Co KG 60/40-63 mesh silica gel for liquid flash chromatography were used. NMR spectra were recorded in $\mathrm{D}_{2} \mathrm{O}$ and $\mathrm{CD}_{3} \mathrm{OD}$ on a Bruker Avance 400 spectrometer. Optical rotation was determined with a P-2000 JASCO PTC-262 polarimeter at the given temperature and wavelength ( $\mathrm{Na}-\mathrm{D}$-line: $\lambda_{\mathrm{D}}=589 \mathrm{~nm}$ ) in a cell $10 \mathrm{~cm}$ long. Optical rotations $\left([\alpha]_{D}\right)$ values are given in $\mathrm{dm}^{-1} \cdot \mathrm{g}^{-1} \cdot \mathrm{cm}^{3}$. HPLC analyses were performed on an Acclaim ${ }^{\mathrm{TM}}$ $120 \mathrm{C} 185 \mu \mathrm{m} 120 \AA$ A $(4.6 \times 250 \mathrm{~nm})$ column from VWR (USA).

In situ ${ }^{1} \mathrm{H}$ NMR measurements. Reactions were monitored using quantitative in situ ${ }^{1} \mathrm{H}$ NMR relative to 3-trimethylsilyl-2,2,3,3tetradeuteropropionate $\left(\right.$ TSP- $\left.\mathrm{d}_{4}\right)$ as internal standard. Aliquots of reaction mixtures $(450 \mu \mathrm{L})$ were mixed with $50 \mu \mathrm{L}$ of $\mathrm{TSP}-\mathrm{d}_{4}$ $(50 \mathrm{mM})$

HPLC measurements. HPLC analyses and derivatisation were performed according to literature [1]. Samples (30 $\mu \mathrm{L})$ were injected and eluted in the following conditions: solvent system (A) $0.1 \%(\mathrm{v} /$ v) aqueous trifluoroacetic acid (TFA) and (B) $0.1 \%(\mathrm{v} / \mathrm{v})$ TFA in $\mathrm{CH}_{3} \mathrm{CN} / \mathrm{H}_{2} \mathrm{O}(4: 1)$, gradient elution $10-95 \% \mathrm{~B}$ in 30 minutes, flow

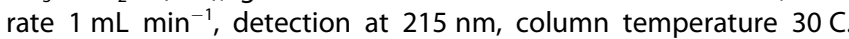
Reaction samples $(10 \mu \mathrm{L})$ were mixed with $50 \mu \mathrm{L}$ of a solution of $O$ benzylhydroxylamine hydrochloride $\left(21.1 \mathrm{mg} \mathrm{mL}^{-1} ; 0.14 \mathrm{mmol} \mathrm{mL}^{-1}\right)$ in pyridine:methanol:water $(33: 15: 2)$. Samples were then diluted in methanol $(500 \mu \mathrm{L})$, centrifuged $\left(5 \mathrm{~min} ., 14,500 \mathrm{rpm}, 25^{\circ} \mathrm{C}\right)$ and the supernatant directly analysed by HPLC.

\section{Preparative-Scale Enzymatic Cascade Synthesis}

Wild-type and variants of L-fructose-6-phosphate aldolase from $E$. coli $\left(\mathrm{FSA}_{\mathrm{eco}}\right)^{[19]}$ wild-type $\mathrm{L}-\alpha$-transaminase from Thermosinus carboxydivorans $\left(\mathrm{TA}_{\mathrm{tca}}\right)^{[18]}$ and wild-type TK from Geobacillus stearothermophilus $\left(\mathrm{TK}_{\mathrm{gst}}{ }^{\left[{ }_{\mathrm{tca}}\right]}\right.$ were produced from recombinant cells and purified as previously described (SI)

Synthesis of L-glyceraldehyde 1. GA $(50 \mathrm{mM})$ and FA $(100 \mathrm{mM})$ were dissolved in $\mathrm{H}_{2} \mathrm{O}(20 \mathrm{~mL})$, and the $\mathrm{pH}$ was adjusted to 8 with $0.1 \mathrm{M} \mathrm{NaOH}$. Wild-type $\mathrm{FSA}_{\text {eco }}(8 \mathrm{mg})$ was added to initiate the reaction, and the mixture was stirred at $50 \mathrm{C}, 100 \mathrm{rpm}$. The reaction was monitored by in situ ${ }^{1} \mathrm{H}$ NMR and HPLC. After complete disappearance of GA (100\% conversion, $19 \mathrm{~h})$, the reaction was stopped and the purity of L-glyceraldehyde 1 was analysed by ${ }^{1} \mathrm{H}$ NMR and HPLC.

(2S)-2,3-dihydroxy-propionaldehyde (L-glyceraldehyde) 1. The title compound was obtained in solution in unbuffered water $R_{\mathrm{f}}$ $0.82\left(\mathrm{CH}_{2} \mathrm{Cl}_{2}: \mathrm{CH}_{3} \mathrm{OH}, 80: 20 \mathrm{v}: \mathrm{v}\right)$. HPLC: $t_{\mathrm{r}}=15.78 \mathrm{~min}$. NMR data were identical to those previously reported. ${ }^{[27]}{ }^{1} \mathrm{H} \mathrm{NMR}(400 \mathrm{MHz}$ $\mathrm{D}_{2} \mathrm{O}$ ): $\delta$ (ppm) (hydrate form): $4.92(\mathrm{~d}, J=5.2 \mathrm{~Hz}, 1 \mathrm{H}, \mathrm{C}-1), 3.73$ (dd, $J=11.1,2.7 \mathrm{~Hz}, 1 \mathrm{H}, \mathrm{H}-3), 3.61\left(\mathrm{~m}, 1 \mathrm{H}, \mathrm{H}-3^{\prime}\right), 3.56(\mathrm{~m}, 1 \mathrm{H}, \mathrm{H}-2) .{ }^{13} \mathrm{C}$ NMR (101 MHz, $\left.\mathrm{D}_{2} \mathrm{O}\right): \delta$ (ppm) (hydrate form): 98.7 (C-1), 74.0 (C-2), $61,6(C-3)$ 
Synthesis of D-threose 2. GA (200 mM) was dissolved in $\mathrm{H}_{2} \mathrm{O}(5 \mathrm{~mL})$ and the $\mathrm{pH}$ was adjusted to 8 with $0.1 \mathrm{M} \mathrm{NaOH}$. FSA eco A129G mutant $(2 \mathrm{mg})$ was added to initiate the reaction, and the mixture was stirred at 25 C, $900 \mathrm{rpm}$. The reaction was monitored by in situ ${ }^{1} \mathrm{H}$ NMR and HPLC. After quasi-complete disappearance of GA (98\% conversion, $24 \mathrm{~h}$ ), the reaction was stopped and the purity of Dthreose 3 was analysed by ${ }^{1} \mathrm{H}$ NMR and HPLC.

(2S,3R)-2,3,4-trihydroxy-butyraldehyde (D-threose) 2 . The title compound was obtained in solution in unbuffered water,. $R_{\mathrm{f}} 0.36$ (EtOAc: $\mathrm{CH}_{3} \mathrm{OH}, 95: 5 \mathrm{v}: \mathrm{v}$ ). HPLC: $t_{\mathrm{r}}=13.96 \mathrm{~min}$. NMR data were identical to those previously reported ${ }^{[28]}$ (ratio $\alpha$-furanose/ $\beta$ furanose/hydrate linear form $=52 / 38 / 10$; lit. ratio $\alpha$-anomer $/ \beta$ anomer/linear hydrate form $=52 / 38 / 10) .{ }^{[29]}{ }^{1} \mathrm{H}$ NMR $\left(400 \mathrm{MHz}, \mathrm{D}_{2} \mathrm{O}\right)$ : $\delta$ (ppm) (hydrate linear form): $5.02(\mathrm{~d}, J=6.3 \mathrm{~Hz}, 1 \mathrm{H}, \mathrm{H}-1), 3.88$ (ddd, $J=7.5,5.0,2.7 \mathrm{~Hz}, 1 \mathrm{H}, \mathrm{H}-3), 3.65(\mathrm{~m}, 1 \mathrm{H}, \mathrm{H}-4), 3.63 \mathrm{ppm}(\mathrm{m}, 1 \mathrm{H}, \mathrm{H}-$ $\left.4^{\prime}\right), 3.45 \mathrm{ppm}(\mathrm{dd}, J=6.2,2.7 \mathrm{~Hz}, 1 \mathrm{H}, \mathrm{H}-2)$; ( $\alpha$-D-threo-1,4-furanose): $5.40(\mathrm{~d}, J=4.2 \mathrm{~Hz}, 1 \mathrm{H}, \mathrm{H}-1), 4.30(\mathrm{~m}, 1 \mathrm{H}, \mathrm{H}-3), 4.17(\mathrm{~m}, 1 \mathrm{H}, \mathrm{H}-4), 4.05$ (m, $1 \mathrm{H}, \mathrm{H}-2)$; ( $\beta$-D-threo-1,4-furanose): $5.24(\mathrm{~d}, J=1.2 \mathrm{~Hz}, 1 \mathrm{H}, \mathrm{H}-1)$, $4.23(\mathrm{~m}, 1 \mathrm{H}, \mathrm{H}-3), 4.21\left(\mathrm{~m}, 1 \mathrm{H}, \mathrm{H}-4^{\prime}\right), 4.03(\mathrm{~m}, 1 \mathrm{H}, \mathrm{H}-2), 3.94(\mathrm{dd}, J=$ 9.2, $2.7 \mathrm{~Hz}, 1 \mathrm{H}, \mathrm{H}-4) .{ }^{13} \mathrm{C}$ NMR $\left(101 \mathrm{MHz}, \mathrm{D}_{2} \mathrm{O}\right): \delta$ (ppm) ( $\alpha$-D-threo1,4-furanose): 103.4 (C-1), 81;9 (C-2), 76.4 (C-3), 74.3 (C-4); ( $\beta$-Dthreo-1,4-furanose): 97.9 (C-1), 77.4 (C-2), 76.1 (C-3), 71.8 (C-4); (hydrate linear form): 91.1 (C-1), 74.5 (C-2), 72.1 (C-3), 64.2 (C-4).

Synthesis of L-erythrose 3. GA $(200 \mathrm{mM})$ was dissolved in $\mathrm{H}_{2} \mathrm{O}$ $(5 \mathrm{~mL})$ and the $\mathrm{pH}$ was adjusted to 8 with $0.1 \mathrm{M} \mathrm{NaOH}$. FSA A165G/S166P mutant $(5 \mathrm{mg})$ was added to initiate the reaction, and the mixture was stirred at $25 \mathrm{C}, 900 \mathrm{rpm}$. After 2, 4, 6 and 8 days, $\mathrm{FSA}_{\text {eco }}$ mutant $\mathrm{A} 165 \mathrm{G} / \mathrm{S} 166 \mathrm{P}(5 \mathrm{mg})$ was added. The reaction was monitored by in situ ${ }^{1} \mathrm{H}$ NMR and HPLC. After quasi-complete disappearance of GA ( $96 \%, 11$ days), the reaction was stopped and the purity of L-erythrose 3 was analysed by ${ }^{1} \mathrm{H}$ NMR and HPLC.

(2S,3S)-2,3,4-trihydroxy-butyraldehyde (L-erythrose) 3 . The title compound was obtained in solution in unbuffered water, $R_{\mathrm{f}} 0.32$ $\left(\mathrm{CH}_{2} \mathrm{Cl}_{2}: \mathrm{CH}_{3} \mathrm{OH}, 90: 10 \mathrm{v}: \mathrm{v}\right)$. HPLC: $t_{\mathrm{r}}=13,74 \mathrm{~min}$. NMR data were identical to those previously reported ${ }^{[27,28]}$ (ratio $\alpha$-L-erythro-1,4furanose/ $\beta$-L-erythro-1,4-furanose/hydrate linear form $=62 / 27 / 11$ ); lit. ratio $\alpha$-L-erythro-1,4-furanose/ $\beta$-L-erythro-1,4-furanose/linear hydrate form $=63 / 20 / 10) .{ }^{[9]}{ }^{13} \mathrm{C} \mathrm{NMR}\left(101 \mathrm{MHz}, \mathrm{D}_{2} \mathrm{O}\right) \delta(\mathrm{ppm}) \quad(\beta-\mathrm{L}-$ erythro-1,4-furanose): 102.4 (C-1), 77.6 (C-2), 72.5 (C-4), 71.7 (C-3); $\delta$ ( $\alpha$-L-erythro-1,4-furanose): 96.8 (C-1), 72,9 (C-4), 72,4 (C-2), 70.6 (C-3); $\delta$ (ppm) (hydrate linear form): $90.7(\mathrm{C}-1), 74.8$ (C-2), 73.0 (C-3), 63.8 (C-4).

General procedure for ketose 4-6 synthesis. ThDP (0.1 mM), $\mathrm{MgCl}_{2} \cdot 6 \mathrm{H}_{2} \mathrm{O}(1 \mathrm{mM}), \mathrm{PLP}(0.2 \mathrm{mM})$ and Pyr $(50 \mathrm{mM})$ were dissolved in $\mathrm{H}_{2} \mathrm{O}$ and the $\mathrm{pH}$ was adjusted to 7 with $0.1 \mathrm{M} \mathrm{NaOH}$. To this stirred solution was added $\mathrm{TK}_{\mathrm{gst}}(6 \mathrm{mg}$ in the case of L-glyceraldehyde; $10 \mathrm{mg}$ in the case of $\mathrm{D}$-threose and L-erythrose) and $\mathrm{TA}_{\text {tca }}$ $(4.8 \mathrm{mg})$, and the mixture was stirred for 20 minutes at $60^{\circ} \mathrm{C}$. In another flask, the reaction mixture containing (2S) $\alpha$-hydroxy aldehydes 1,2 or 3 obtained previously with $\mathrm{FSA}_{\text {eco }}$ was diluted to obtain a concentration of $50 \mathrm{mM}$ (except for L-glyceraldehyde) and L-Ser $(150 \mathrm{mM})$ were mixed and the $\mathrm{pH}$ adjusted to 7 with $0.1 \mathrm{M}$ $\mathrm{NaOH}$. After pre-incubation of enzymes, cofactors and Pyr, L-Ser and (2S) $\alpha$-hydroxy aldehydes $(50-100 \mathrm{mM})$ in the reaction mixture were added, and the mixture was stirred at $60^{\circ} \mathrm{C}$. The final volume was $20 \mathrm{~mL}$. The $\mathrm{pH}$ was maintained at 7 by adding $0.1 \mathrm{M} \mathrm{HCl}$ using a pH stat (Radiometer Analytical). The reaction was monitored by measuring Pyr and (2S) $\alpha$-hydroxy aldehydes consumption by in situ ${ }^{1} \mathrm{H}$ NMR. In the case of D-threose and L-erythrose, the complete disappearance of Pyr was observed after $48 \mathrm{~h}$ and a second portion of Pyr ( $50 \mathrm{mM}$ ) was added. After total conversion of Pyr and (2S)- $\alpha$ hydroxy aldehydes (24-96 h), silica was added to the solution, and the suspension was concentrated to dryness under reduced pressure and loaded onto a flash silica column. After silica gel chromatography using $\mathrm{CH}_{2} \mathrm{Cl}_{2}: \mathrm{CH}_{3} \mathrm{OH}$ v:v 90:10 as eluent (for Lribulose 4) and EtOAc: $\mathrm{CH}_{3} \mathrm{OH}$ v:v 100:0-90:10 as eluent (for Dtagatose 5 and L-psicose 6), compounds 4, 5 and 6 were isolated.

(3S,4S)-1,3,4,5-tetrahydroxypentan-2-one (L-ribulose) 4 . The title compound was isolated as a yellow oil; yield: $84 \mathrm{mg}, 56 \% . R_{\mathrm{f}} 0.43$ $\left(\mathrm{DCM} / \mathrm{CH}_{3} \mathrm{OH}, 8: 2\right) .[\alpha]_{D}{ }^{20}=+15.8\left(\mathrm{c} 0.1, \mathrm{H}_{2} \mathrm{O}\right)$ lit. $[\alpha]_{D}{ }^{20}=+16.5 \pm$ 1.5 (c $0.1 \mathrm{H}_{2} \mathrm{O}$ ). NMR data were identical to those previously described $^{[30]}$ (ratio $\alpha$-anomer/ $\beta$-anomer/linear form $=63 / 23 / 14$; lit. ratio $\alpha$-anomer/ $\beta$-anomer/linear form $=58 / 24 / 18) .{ }^{[30]}{ }^{13} \mathrm{C} \quad \mathrm{NMR}$ (101 MHz, $\left.\mathrm{D}_{2} \mathrm{O}\right): \delta$ (ppm) (linear form) 213.9 (C-2), 76.8 (C-3), 74.0 (C4), 67.9 (C-1), 62.7 (C-5); $\delta$ (ppm) ( $\alpha$-anomer) $104.0(\mathrm{C}-2), 72.9$ (C-5), 71.9 (C-3), 64.2 (C-4), 71.6 (C-1); $\delta$ (ppm) ( $\beta$-anomer) 107.1 (C-2), 77.2 (C-3), 72.2 (C-5), 72.0 (C-4), 63.9 (C-1). m/z HRMS found [M+ $\mathrm{Cl}^{-} 185.0212, \mathrm{C}_{5} \mathrm{H}_{10} \mathrm{O}_{5} \mathrm{Cl}$ requires 185.0217 .

(3S,4S,5R)-1,3,4,5,6-pentahydroxyhexan-2-one (D-tagatose) 5 . The title compound was isolated as a white powder; yield: $93 \mathrm{mg}, 52 \%$. $R_{\mathrm{f}} 0.31\left(\mathrm{DCM} / \mathrm{CH}_{3} \mathrm{OH}, 8: 2\right)$. $[\alpha]_{\mathrm{D}}{ }^{25}=-2.9\left(\mathrm{c} 2, \mathrm{H}_{2} \mathrm{O}\right)$ lit. $[\alpha]_{\mathrm{D}}{ }^{20}=-2.5 .^{[31]}$ NMR data were identical to those previously described ${ }^{[32]}$ (ratio $\alpha$-Dtagato-2.6-pyranose/ $\beta$-D-tagato-2.6-pyranose/ $\alpha$-D-tagato-2.5-furanose $/ \beta$-D-tagato-2.6-furanose $=72 / 22 / 2 / 4$.; lit. ratio $\alpha$-D-tagato-2.6pyranose/ $\beta$-D-tagato-2.6-pyranose/ $\alpha$-D-tagato-2.5-furanose/ $\beta$-D-tagato-2.6-furanose $=79 / 14 / 2 / 5) .{ }^{[3]]}{ }^{13} \mathrm{C}$ NMR $\left(101 \mathrm{MHz}, \mathrm{D}_{2} \mathrm{O}\right) \delta(\mathrm{ppm})$ ( $\alpha$-D-tagato-2.6-pyranose): 99.0 (C-2), 71.8 (C-4), 70.6 (C-3), 67.2 (C5), 64.7 (C-1), 63.1 (C-6); $\delta$ (ppm) ( $\beta$-D-tagato-2.6-pyranose): 99.1 (C2), 70.6 (C-4), 70.1 (C-5), 64.5 (C-3), 64.3 (C-1); 60.9 (C-6); $\delta(\mathrm{ppm})(\alpha-$ D-tagato-2.5-furanose): 105.8 (C-2), 80.0 (C-5), 77.5 (C-3), 71.9 (C 4), $63.2(\mathrm{C}-1), 62.6(\mathrm{C}-6) ; \delta$ (ppm) ( $\beta$-D-tagato-2.6-furanose): $103.4(\mathrm{C}-2)$, 80.9 (C-5), 71.8 (C-4), 71.5 (C3), 63.4 (C-1), 61.8 (C-6). m/z HRMS found $[\mathrm{M}+\mathrm{Cl}]^{-} 215.0319, \mathrm{C}_{6} \mathrm{H}_{12} \mathrm{O}_{6} \mathrm{Cl}$ requires 215.0322 .

$(3 S, 4 S, 5 S)-1,3,4,5,6$-pentahydroxyhexan-2-one (L-psicose) 6. The title compound_was isolated as a white powder; yield: $92 \mathrm{mg}, 51 \%$. $R_{\mathrm{f}} 0.31\left(\mathrm{DCM} / \mathrm{CH}_{3} \mathrm{OH}, 8: 2\right) .[\alpha]_{\mathrm{D}}{ }^{20}=-2.3\left(\right.$ c $\left.0.1 \mathrm{H}_{2} \mathrm{O}\right)$ lit. $[\alpha]_{\mathrm{D}}{ }^{20}=$ $-2.4 .^{[34]}$ Data for D-psicose: $+3.02\left(c=1.16 \text { in } \mathrm{H}_{2} \mathrm{O}\right)^{[44]},+3.1(c=1.62$ in $\left.\mathrm{H}_{2} \mathrm{O}\right) .{ }^{[35]}$ NMR data were identical to those previously described for the $D$ enantiomer: ${ }^{[32,36]}$ (ratio $\alpha$-D-psico-2.6-pyranose/ $\beta$-D-psico2.6-pyranose/ $\alpha$-D-psico-2.5-furanose/ $\beta$-D-psico-2.6-furanose $=25$ / 24/37/13; lit. ratio $\alpha$-D-psico-2.6-pyranose/ $\beta$-D-psico-2.6-pyranose/ $\alpha$-D-psico-2.5-furanose/ $\beta$-D-psico-2.6-furanose $=22 / 24 / 39 / 15) . \quad{ }^{1} \mathrm{H}$ NMR $\left(400 \mathrm{MHz}, \mathrm{D}_{2} \mathrm{O}\right) \delta(\mathrm{ppm}) 3.43(\mathrm{~d}, J=11.7 \mathrm{~Hz}), 3.87-3.51(\mathrm{~m})$, 4.11-3.91 (m), $4.09(\mathrm{~s}), 4.33$ (dd, $J=7.6,4.7 \mathrm{~Hz}) .{ }^{13} \mathrm{C}$ NMR $(101 \mathrm{MHz}$, $\left.\mathrm{D}_{2} \mathrm{O}\right) \delta$ (ppm) ( $\alpha$-D-psico-2,6-pyranose) 98.6 (C-2), 72.6 (C-4), 66.8 (C5), 66.4 (C-3), 64.0 (C-1), 58.9 (C-6); $\delta$ (ppm) ( $\beta$-D-psico-2,6-pyranose) 99.3 (C-2), 71.12 (C-3), 69.9 (C-5), 66.0 (C-4), 65.1 (C-6), 64.9 (C-1); $\delta$ (ppm) ( $\alpha$-D-psico-2,5-furanose) 104.2 (C-2), 83.6 (C-5), 71.2 (C-4), 71.2 (C-3), 64.2 (C-1), 62.2 (C-6); $\delta$ (ppm) ( $\beta$-D-psico-2,6-furanose) 106.5 (C-2), 83.6 (C-5), 75.5 (C-3), 71.9 (C-4), 63.7 (C-6), $63.3(\mathrm{C}-1) . \mathrm{m} /$ $z$ HRMS found $[\mathrm{M}+\mathrm{Cl}]^{-} 215.0318, \mathrm{C}_{6} \mathrm{H}_{12} \mathrm{O}_{6} \mathrm{Cl}$ requires 215.0322 .

\section{Acknowledgements}

The authors thank the French National Research Agency (grant ANR-13-IS07-0003-01 to L.H), the Ministerio de Economía y Competitividad (MINECO), the Fondo Europeo de Desarrollo Regional (FEDER) (grant RTI2018-094637-B-100), COST Action CM1303 "Systems Biocatalysis" (financial support of a short-term scientific mission in Barcelona to M.L) and ERACoBioTech (European Union's Horizon 2020 research and innovation programme under grant agreement No [722361] to L.H., P.C and W.D.F). 


\section{Conflict of Interest}

The authors declare no conflict of interest.

Keywords: biocatalysis - transketolase - transaminase $\cdot$ fructose6-phosphate aldolase • hydroxypyruvate • ketoses stereoselectivity.

[1] R. A. Sheldon, J. M. Woodley, Chem. Rev. 2018, 118, 801-838.

[2] J. H. SchrittwieSer, S. Velikogne, M. Hall, W. Kroutil, Chem. Rev. 2018, $118,270-348$.

[3] J. M. Sperl, V. Sieber, ACS Catal. 2018, 8, 2385-2396.

[4] S. Wu, Z. Li, ChemCatChem. 2017, 10, 2164-2178.

[5] P. Clapes, W.-D. Fessner, G. Sprenger, A. K. Samland, Curr. Opin. Chem. Biol. 2010, 14, 154-167.

[6] M. Müller, D. Gocke, M. Pohl, FEBS J. 2009, 27, 2894-2904.

[7] a) Y. Kobori, D. C. Myles, G. M. Whitesides, J. Org. Chem. 1992, 57,58995907 ; b) S. R. Marsden, L. Gjonaj, S. J. Eustace, U. Hanefeld, ChemCatChem. 2017, 9, 1808-1814.

[8] a) T. Ziegler, A. Straub, F. Effenberger, Angew. Chem. Int. Ed. 1988, 100, 737-738; b) L. Hecquet, J. Bolte, C. Demuynck, Tetrahedron. 1996, 52, 8223-8232; c) F. T. Zimmermann, A. Schneider, U. Schörken, G. A. Sprenger, W.-D. Fessner, Tetrahedron: Asymmetry. 1999, 10, 1643-1646; d) N. J. Turner, Curr. Opin. Biotechnol. 2000, 11, 527-531; e) F. Charmantray, V. Helaine, B. Legeret, L. Hecquet, J. Mol. Catal. B 2009, 57, 6-9.

[9] a) J. L. Galman, D. Steadmann, S. Bacon, P. Morris, M. E. B. Smith, J. Ward, P. A. Dalby, H. C. Hailes, Chem. Commun. 2010, 46, 7608-7610; b) A. Cázares, J. L. Galman, L. G. Crago, M. E. Smith, J. Strafford, L. RíosSolís, G. L. Lye, P. A. Dalby, H. C. Hailes, Org. Biomol. Chem. 2010, 8, 1301-1130; c) F. Subrizi, M. Cárdenas-Fernández, G. J. Lye, J. M. Ward, P. A. Dalby, T. D. Sheppard, H. C. Hailes, Green Chem. 2016, 18, 31583165.

[10] A. Ranoux, S. K. Karmee, J. Jin, A. Bhaduri, A. Caiazzo, I. W. Arends, U. Hanefeld, ChemBioChem. 2012, 13, 1921-1931.

[11] J. Abdoul Zabar, I. Sorel, V. Hélaine, F. Charmantray, T. Devamani, D. Yi, V. de Berardinis, D. Louis, P. Marlière, W.-D. Fessner, L. Hecquet, Adv. Synth. Catal. 2013, 355, 116-128.

[12] G. Ali, T. Moreau, C. Forano, C. Mousty, V. Prevot, F. Charmantray, L. Hecquet, ChemCatChem. 2015, 7, 3163-3170.

[13] a) J. Abdoul Zabar, M. Lorillière, D. Yi, S. Thangavelu, T. Devamini, L. Nauton, F. Charmantray, V. Hélaine, W.-D. Fessner, L. Hecquet, Adv. Synth. Catal. 2015, 357, 1715-1720; b) M. Lorillière, R. Dumoulin, M. L'enfant, A. Rambourdin, V. Thery, L. Nauton, W.-D Fessner, F. Charmantray, L. Hecquet, ACS Catal. 2019, 9, 4754-4763.

[14] T. Saravanan, T. Devamani, F. Charmantray, L. Hecquet, W.-D. Fessner, Chem. Commun. 2015, 51, 480-483.

[15] T. Saravanan, M. L. Reif, D. Yi, M. Lorillière, F. Charmantray, L. Hecquet, W.-D. Fessner, Green Chem. 2017, 19, 481-489.
[16] T. Saravanan, S. Junker, M. Kickstein, J. Hegen, Hein, M. K. Link, S. Witt M. Lorillière, L. Hecquet, W.-D. Fessner, Angew. Chem. Int. Ed. 2017, 56, 5358-5362.

[17] a) L. Hecquet, J. Bolte, C. Demuynck, Tetrahedron. 1996, 52, 8223-8232; b) M. Bawn, F. Subrizi, G. J. Lye, T. D. Sheppard, H. C. Hailes, J. M. Ward, Enzyme Microb. Technol. 2018, 116, 16-22.

[18] M. Lorillière, M. De Sousa, F. Bruna, E. Heuson, T. Gefflaut, V. de Berardinis, T. Saravanan, D. Yi, W.-D. Fessner, F. Charmantray, L. Hecquet, Green Chem. 2017, 19, 425-435.

[19] A. Szekrenyi, X. Garrabou, T. Parella, J. Joglar, J. Bujons, P. Clapés, Nat. Chem. 2015, 7, 724-729.

[20] C. Guérard-Hélaine, M. De Sousa Lopes Moreira, N. Touisni, L. Hecquet, M. Lemaire, V. Hélaine, Adv. Synth. Catal. 2017, 359, 2061-2065.

[21] a) A. Kylmä, T. Granström, M. Leisola, Appl. Microbiol. Biotechnol. 2004 63, 584-591; b) K. Vanhessche, E. Van der Eyckenand, M. Vandewalle, Tetrahedron Lett. 1990, 31, 2337-2340; c) G. Gumina, G. Y. Song, C. K Chu, FEMS Microbiol. Lett. 2001, 202, 9-15.

[22] D.-K. Oh, Appl. Microbiol. Biotechnol. 2007, 76, 1-8.

[23] a) Y. Terami, K. Uechi, S. Nomura, N. Okamoto, K. Morimoto, G. Takata, Biosci. Biotechnol. Biochem. 2015, 79, 1725-9; b) D. Rao, P. Gullapalli, A. Yoshihara, S. F. Jenkinson, K. Morimoto, G. Takata, K. Akimitsu, S. Tajima, G. W. Fleet, K. Izumori, J. Biosci. Bioeng. 2008, 106, 473-80.

[24] M. Schurmann, G. A. Sprenger, J. Biol. Chem. 2001, 276, 11055-11061.

[25] R. Roldán, I. Sanchez-Moreno, T. Scheidt, V. Hélaine, M. Lemaire, T. Parella, P. Clapés, W.-D. Fessner, C. Guérard-Hélaine, Chem. Eur. J. 2017 23, 5005-5009.

[26] a) D. Güclü, A. Szekrenyi, X. Garrabou, M. Kickstein, S. Junker, P. Clapés, W.-D. Fessner, ACS Catal. 2016, 6, 1848-1852. b) R. Roldán, K Hernandez, J. Joglar, J. Bujons, T. Parella, I. Sánchez-Moreno, V. Hélaine, M. Lemaire, C. Guérard-Hélaine, W.-D. Fessner, P. Clapés, ACS Catal. 2018, 8, 8804-8809.

[27] X. Garrabou, J. A. Castillo, C. Guérard-Hélaine, T. Parella, J. Joglar, M. Lemaire, P. Clapés, Angew. Chem. Int. Ed. 2009, 48, 5521-5525.

[28] A. S. Serianni, E. L. Clark, R. C. Barker, Carbohydr. Res. 1979, 72, 79-91.

[29] C. André, J. Bolte, C. Demuynck, Tetrahedron: Asymmetry. 1998, 9, 13591367.

[30] T. Vuorinen, A. S. Serianni, Carbohydr. Res. 1991, 209, 13-31.

[31] K. Yoshihara, Y. Shinohara, T. Hirotsu, K. Izumori, J. Biosci. Bioeng. 2006, $101,219-222$.

[32] J.-P. Sauvage, S. Chapelle, J.-F. Verchère, Carbohydr. Res. 1992, 237, 2332.

[33] S. Köpper, S. Freimund, Helv. Chim. Acta. 2003, 86, 827-843.

[34] K. Takeshita, T. Shimonishi, K. Izumori, J. Biosci. Bioeng. 1996, 81, 212215.

[35] M. Steiger, T. Reichstein, Helv. Chim. Acta. 1936, 19, 184-189.

[36] D. Enders, C. Grondal, Angew. Chem. Int. Ed. 2005, 8, 1210-1212. 